University of Wollongong

Research Online

Australian Institute for Innovative Materials -

Papers

Australian Institute for Innovative Materials

$1-1-2010$

\title{
Li2B12H12-7NH3: a new ammine complex for ammonia storage or indirect hydrogen storage
}

\author{
Zhenguo Huang \\ The Ohio State University, zhenguo@uow.edu.au \\ Judith C. Gallucci \\ Ohio State University \\ Xuenian Chen \\ Ohio State University \\ Teshome B. Yisgedu \\ Ohio State University \\ Hima Kumar Lingam \\ Ohio State University
}

See next page for additional authors

Follow this and additional works at: https://ro.uow.edu.au/aiimpapers

Part of the Engineering Commons, and the Physical Sciences and Mathematics Commons

Research Online is the open access institutional repository for the University of Wollongong. For further information contact the UOW Library: research-pubs@uow.edu.au 


\title{
Li2B12H12·7NH3: a new ammine complex for ammonia storage or indirect hydrogen storage
}

\author{
Abstract \\ A new ammine complex, $\mathrm{Li} 2 \mathrm{~B} 12 \mathrm{H} 12 \$ 7 \mathrm{NH} 3$, that can reversibly release all the $\mathrm{NH} 3$ at below $200 \mathrm{oC}$ and \\ reabsorb $\mathrm{NH} 3$ at room temperature and 0.5 bar was synthesized and investigated for reversible ammonia \\ storage or indirect hydrogen storage.

\section{Keywords} \\ complex, ammine, 7nh3, li2b12h12, hydrogen, indirect, storage, ammonia \\ Disciplines \\ Engineering | Physical Sciences and Mathematics

\section{Publication Details} \\ Huang, Z., Gallucci, J., Chen, X., Yisgedu, T., Lingam, H. Kumar., Shore, S. G. \& Zhao, J. (2010). \\ Li2B12H12.7NH3: a new ammine complex for ammonia storage or indirect hydrogen storage. Journal of \\ Materials Chemistry, 20 2743-2745.

\section{Authors} \\ Zhenguo Huang, Judith C. Gallucci, Xuenian Chen, Teshome B. Yisgedu, Hima Kumar Lingam, Sheldon G. \\ Shore, and Ji-Cheng Zhao
}




\title{
$\mathrm{Li}_{2} \mathrm{~B}_{12} \mathrm{H}_{12} \cdot 7 \mathrm{NH}_{3}$ : a new ammine complex for ammonia storage or indirect hydrogen storage $\dagger$
}

\author{
Zhenguo Huang, ${ }^{a}$ Judith Gallucci, ${ }^{b}$ Xuenian Chen, ${ }^{b}$ Teshome Yisgedu, ${ }^{a}$ Hima Kumar Lingam, ${ }^{a}$ \\ Sheldon G. Shore ${ }^{b}$ and Ji-Cheng Zhao*a
}

\author{
Received 13th November 2009, Accepted 5th February 2010 \\ First published as an Advance Article on the web 25th February 2010 \\ DOI: $10.1039 / b 923829 h$
}

\begin{abstract}
A new ammine complex, $\mathrm{Li}_{2} \mathrm{~B}_{12} \mathrm{H}_{12} \cdot 7 \mathrm{NH}_{3}$, that can reversibly release all the $\mathrm{NH}_{3}$ at below $200{ }^{\circ} \mathrm{C}$ and reabsorb $\mathrm{NH}_{3}$ at room temperature and 0.5 bar was synthesized and investigated for reversible ammonia storage or indirect hydrogen storage.
\end{abstract}

All direct hydrogen storage materials under investigation today fall short of the US DOE targets. ${ }^{1}$ None of the high-capacity (high weight percent) hydrogen storage materials works at mild operating conditions and has good reversibility. ${ }^{2}$ Therefore, ammonia has been proposed as an alternative hydrogen carrier. ${ }^{3}$ Molecular ammonia contains $17.8 \mathrm{wt} \% \mathrm{H}$ and can be catalytically converted to hydrogen and nitrogen at temperatures below $380{ }^{\circ} \mathrm{C}$ in high yields. ${ }^{4}$ The most recent research on reversible $\mathrm{NH}_{3}$ storage illustrates how a practical, reversible storage capacity of up to $10 \mathrm{wt} \% \mathrm{H}$ can be achieved by metal ammines such as $\mathrm{Mg}\left(\mathrm{NH}_{3}\right)_{6} \mathrm{Cl}_{2}$ and $\mathrm{Ca}\left(\mathrm{NH}_{3}\right)_{8} \mathrm{Cl}_{2} .{ }^{3}$ $\mathrm{Mg}\left(\mathrm{NH}_{3}\right)_{6} \mathrm{Cl}_{2}$, for example, releases 4 of the 6 ammonia molecules at around $170{ }^{\circ} \mathrm{C}$ and the remaining 2 ammonia below $425^{\circ} \mathrm{C}$, totaling $9.19 \mathrm{wt}^{\%} \% \mathrm{H}$ indirectly, and fully absorbs ammonia at room temperature under about 4 bar ammonia overnight. Furthermore, a highly developed ammonia infrastructure including manufacturing, handling, and transporting is already well established around the world. ${ }^{5}$ This gives an advantage for using ammonia as an energy carrier over hydrogen, at least for the short term.

Although there exist many ammine complexes, ${ }^{6}$ so far, only a handful of them such as $\mathrm{Ca}\left(\mathrm{NH}_{3}\right)_{8} \mathrm{Cl}_{2}, \mathrm{Mg}\left(\mathrm{NH}_{3}\right)_{6} \mathrm{Cl}_{2}$, and $\mathrm{Ni}\left(\mathrm{NH}_{3}\right)_{6} \mathrm{Cl}_{2}$ have been investigated for indirect hydrogen storage applications, due to the requirements of storage capacity and operating conditions. Therefore, a proper combination of cation and anion which leads to a suitable structure that favors the ammonia pickup and release is key to the search for reversible ammonia storage. The resistance to hydrolysis and oxidation and the high thermal stability of dodecahydro-closo-dodecaborate ${ }^{7}$ make $\left[\mathrm{B}_{12} \mathrm{H}_{12}\right]^{2-}$ an interesting anion for the ammine complex. In order to improve the gravimetric capacity for the ammonia storage, the lightest metal cation, $\mathrm{Li}$, was chosen to balance the electric charge. In this paper, a new ammine complex, $\mathrm{Li}_{2} \mathrm{~B}_{12} \mathrm{H}_{12} \cdot 7 \mathrm{NH}_{3}$, is discussed in terms of its structure, indirect hydrogen storage capacity, reversibility,

${ }^{a}$ Department of Materials Science and Engineering, The Ohio State University, Columbus, OH, 43210, USA

${ }^{b}$ Department of Chemistry, The Ohio State University, Columbus, $\mathrm{OH}$, 43210,USA.E-mail: zhao.199@osu.edu

$\dagger$ Electronic supplementary information (ESI) available: Experimental details on synthesis and characterization of both $\mathrm{Li}_{2} \mathrm{~B}_{12} \mathrm{H}_{12}$ and $\mathrm{Li}_{2} \mathrm{~B}_{12} \mathrm{H}_{12} \cdot 7 \mathrm{NH}_{3}$. CCDC reference number 761426. For ESI and crystallographic data in CIF or other electronic format see DOI: 10.1039/b923829h and thermal stability. Based on this compound, a series of dodecahydro-closo-dodecaborate ammine complexes with different cations can be synthesized and more information can be obtained for indirect hydrogen storage.

All synthesis procedures were performed in a standard highvacuum line and a glove box unless otherwise stated. Solvents and ammonia are dried prior to use. $\mathrm{Li}_{2} \mathrm{~B}_{12} \mathrm{H}_{12}$ was prepared according to the published method. ${ }^{8} \mathrm{Li}_{2} \mathrm{~B}_{12} \mathrm{H}_{12} \cdot 7 \mathrm{NH}_{3}$ was obtained by charging anhydrous $\mathrm{Li}_{2} \mathrm{~B}_{12} \mathrm{H}_{12}$ with either dry gaseous ammonia at room temperature or dry liquid ammonia at $-78{ }^{\circ} \mathrm{C}$. Thin plate-shaped colorless single $\mathrm{Li}_{2} \mathrm{~B}_{12} \mathrm{H}_{12} \cdot 7 \mathrm{NH}_{3}$ crystals were produced in tetrahydrofuran solution. X-Ray single crystal diffraction data were collected on a Nonius Kappa CCD diffractometer and analyzed using SHELXTL-97 structure solution package to resolve the structure. ${ }^{9} \mathrm{X}$-Ray powder diffraction (XRD), thermogravimetric analysis (TGA), differential scanning calorimetry (DSC) and infrared (IR) absorption techniques were also applied for characterization.

The crystallographic data are listed in Table 1. Selected bond lengths and bond angles are given in Table 2. The structure is depicted in Fig. 1. The new compound is ionic and consists of $\left[\mathrm{Li}\left(\mathrm{NH}_{3}\right)_{3}\right]^{+},\left[\mathrm{Li}\left(\mathrm{NH}_{3}\right)_{4}\right]^{+}$, and anion $\left[\mathrm{B}_{12} \mathrm{H}_{12}\right]^{2-}$. This structure is quite different from heptahydrate $\mathrm{Li}_{2} \mathrm{~B}_{12} \mathrm{H}_{12} \cdot 7 \mathrm{H}_{2} \mathrm{O}^{8}$ where water molecules form two $\left[\mathrm{Li}\left(4 \mathrm{H}_{2} \mathrm{O}\right)\right]^{+}$tetrahedra with eclipsed conformation, and the tetrahedra links to a dimer via a common corner.

The ammonia bound to the central Li cation in the $\left[\mathrm{Li}\left(\mathrm{NH}_{3}\right)_{4}\right]^{+}$ occupy the corners of a distorted tetrahedron. The angle of $96.4(2)^{\circ}$ between $\mathrm{N}_{1}-\mathrm{Li}_{1}-\mathrm{N}_{2}$ is almost the same as $97.8(2)^{\circ}$ of $\mathrm{N}_{3}-\mathrm{Li}_{1}-\mathrm{N}_{4}$, but much smaller than $120.7(2)^{\circ}$ of $\mathrm{N}_{1}-\mathrm{Li}_{1}-\mathrm{N}_{3}$ and $121.7(2)^{\circ}$ of $\mathrm{N}_{2}-\mathrm{Li}_{1}-$ $\mathrm{N}_{4}$. The Li-N distances are about the same, within 3 esd's, from

Table 1 Crystallographic information for $\mathrm{Li}_{2} \mathrm{~B}_{12} \mathrm{H}_{12} \cdot 7 \mathrm{NH}_{3}$

\begin{tabular}{|c|c|}
\hline Empirical formula & $\mathrm{H}_{33} \mathrm{~B}_{12} \mathrm{Li}_{2} \mathrm{~N}_{7}$ \\
\hline Formula weight & 274.93 \\
\hline Lattice & Monoclinic \\
\hline Space group & $P 2_{1} / n$ \\
\hline$Z$ & 4 \\
\hline$D_{\text {calcd }} / \mathrm{g} \mathrm{cm}^{-3}$ & 0.961 \\
\hline a/A & $8.3050(17)$ \\
\hline b/A & $14.729(3)$ \\
\hline$c / \AA$ & $15.728(3)$ \\
\hline$\beta /^{\circ}$ 。 & $98.90(3)$ \\
\hline$V / \AA^{3}$ & $1900.7(7)$ \\
\hline$T /{ }^{\circ} \mathrm{C}$ & -123 \\
\hline$\mu / \mathrm{mm}^{-1}$ & 0.051 \\
\hline$R 1[I>2 \sigma(I)]^{a}$ & 0.0584 \\
\hline w $R 2$ (all data) ${ }^{b}$ & 0.1849 \\
\hline
\end{tabular}


Table 2 Selected bond lengths and angles

\begin{tabular}{llr}
\hline Distance/A & $\mathrm{Li}_{1}-\mathrm{N}_{1}$ & $2.096(4)$ \\
& $\mathrm{Li}_{1}-\mathrm{N}_{2}$ & $2.095(4)$ \\
& $\mathrm{Li}_{1}-\mathrm{N}_{3}$ & $2.082(4)$ \\
& $\mathrm{Li}_{1}-\mathrm{N}_{4}$ & $2.095(4)$ \\
& $\mathrm{Li}_{2}-\mathrm{N}_{5}$ & $2.045(4)$ \\
& $\mathrm{Li}_{2}-\mathrm{N}_{6}$ & $2.048(5)$ \\
& $\mathrm{Li}_{2}-\mathrm{N}_{7}$ & $2.038(5)$ \\
Angles $^{\circ}$ & $\mathrm{N}_{1}-\mathrm{Li}_{1}-\mathrm{N}_{2}$ & $96.4(2)$ \\
& $\mathrm{N}_{1}-\mathrm{Li}_{1}-\mathrm{N}_{3}$ & $120.7(2)$ \\
& $\mathrm{N}_{1}-\mathrm{Li}_{1}-\mathrm{N}_{4}$ & $100.7(1)$ \\
$\mathrm{N}_{2}-\mathrm{Li}_{1}-\mathrm{N}_{3}$ & $119.7(1)$ \\
$\mathrm{N}_{2}-\mathrm{Li}_{1}-\mathrm{N}_{4}$ & $121.7(2)$ \\
& $\mathrm{N}_{3}-\mathrm{Li}_{1}-\mathrm{N}_{4}$ & $97.8(2)$ \\
$\mathrm{N}_{5}-\mathrm{Li}_{2}-\mathrm{N}_{6}$ & $111.7(2)$ \\
$\mathrm{N}_{5}-\mathrm{Li}_{2}-\mathrm{N}_{7}$ & $111.2(2)$ \\
& $\mathrm{N}_{6}-\mathrm{Li}_{2}-\mathrm{N}_{7}$ & $110.0(2)$ \\
\hline
\end{tabular}

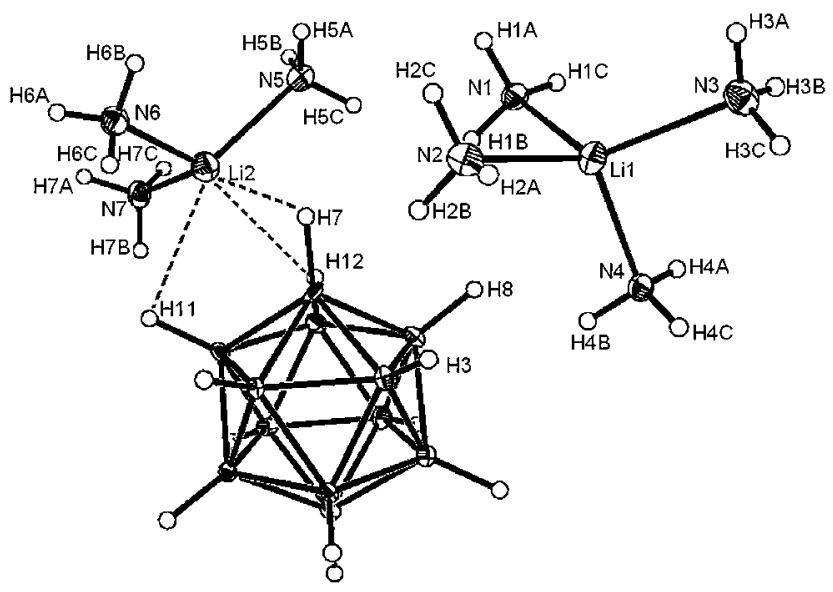

Fig. 1 Asymmetric unit of $\mathrm{Li}_{2} \mathrm{~B}_{12} \mathrm{H}_{12} \cdot 7 \mathrm{NH}_{3}$, showing $25 \%$ probability thermal ellipsoids. Hydrogen atoms are drawn with an arbitrary radius.

2.096(4) $\AA$ of $\mathrm{Li}_{1}-\mathrm{N}_{1}$ to 2.082(4) $\AA$ of $\mathrm{Li}_{1}-\mathrm{N}_{3}$. With respect to $\left[\mathrm{Li}\left(\mathrm{NH}_{3}\right)_{3}\right]^{+}$, the $3 \mathrm{Li}-\mathrm{N}$ angles have a much smaller range of values (111.0 to $111.7^{\circ}$ ) than that in the tetrahedral $\left[\mathrm{Li}\left(\mathrm{NH}_{3}\right)_{4}\right]^{+}$, and $\mathrm{Li}-\mathrm{N}$ distance is similar, i.e. about $2.045 \AA$. The $\mathrm{Li}-\mathrm{N}$ distance in $\left[\mathrm{Li}\left(\mathrm{NH}_{3}\right)_{3}\right]^{+}$is shorter than that in the tetrahedral $\left[\mathrm{Li}\left(\mathrm{NH}_{3}\right)_{4}\right]^{+}$, where the extra $\mathrm{N}$ atom increases the steric hindrance and electric repulsion. The Li cation is situated above the center of the trigonal plane formed by the three $\mathrm{N}$ atoms, and is coordinated to three $\mathrm{B}-\mathrm{H}$ vertices. On the contrary, the $\left[\mathrm{Li}\left(\mathrm{NH}_{3}\right)_{4}\right]^{+}$is attracted to the $\left[\mathrm{B}_{12} \mathrm{H}_{12}\right]^{2-}$ through Coulomb attraction, since the shortest $\mathrm{H}-\mathrm{H}$ distance $\left(\mathrm{H}_{2 \mathrm{~B}}-\mathrm{H}_{3}\right)$ is 2.280(7) $\AA$, much longer than the common dihydrogen bond lengths, $1.7-2.2 \AA^{10}$

The reversibility of ammonia storage can be demonstrated through powder XRD pattern (Fig. 2). The starting anhydrous $\mathrm{Li}_{2} \mathrm{~B}_{12} \mathrm{H}_{12}$ was charged with ammonia by two means: under 0.5 bar ammonia and liquid ammonia. Both ways produce the same ammine complex as indicated by the XRD pattern (Fig. 2, b and c). The desorption was carried out at $200^{\circ} \mathrm{C}$ under dynamic vacuum. The temperature was chosen based on the DSC and TGA results which are discussed later in the paper. It is clear that after the 1st and 3rd desorption, the host material maintains the same structure as the starting anhydrous $\mathrm{Li}_{2} \mathrm{~B}_{12} \mathrm{H}_{12}$ (Fig. 2, a, d, and f). The ammine complex after the 1st and 3rd charge also shares the same structure as indicated by the powder

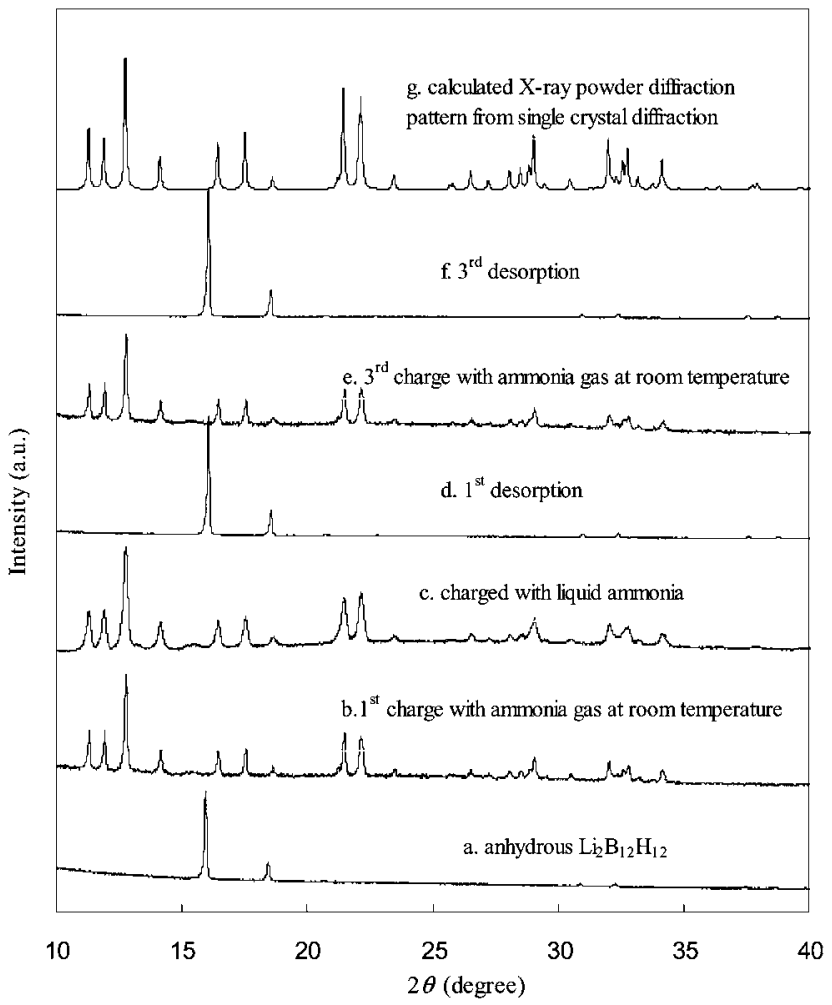

Fig. 2 Powder XRD patterns. Samples were loaded into capillaries and sealed in a glove box.

XRD pattern, which is identical to the calculated pattern based on single crystal diffraction of $\mathrm{Li}_{2} \mathrm{~B}_{12} \mathrm{H}_{12} \cdot 7 \mathrm{NH}_{3}$ (Fig. 2, b, e and g).

The infrared absorption of the anhydrous $\mathrm{Li}_{2} \mathrm{~B}_{12} \mathrm{H}_{12}$ and ammine complex is shown in Fig. 3. The integrity of the boron cage after desorption was verified again since the spectrum from the anhydrous $\mathrm{Li}_{2} \mathrm{~B}_{12} \mathrm{H}_{12}$ shows the same absorption peaks as after the 3rd desorption (Fig. 3, a and c). Note that the characteristic stretching absorption peak from B-H at $2470 \mathrm{~cm}^{-1}$ splits into $2458 \mathrm{~cm}^{-1}$ and $2515 \mathrm{~cm}^{-1}$ for the anhydrous $\mathrm{Li}_{2} \mathrm{~B}_{12} \mathrm{H}_{12}$. The split was also found for

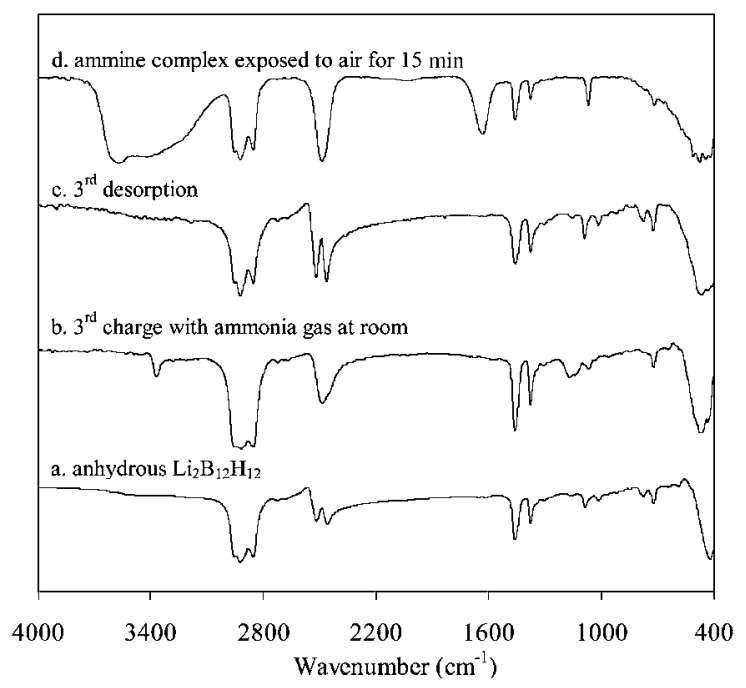

Fig. 3 IR spectra. Samples were suspended in IR grade mineral oil. 


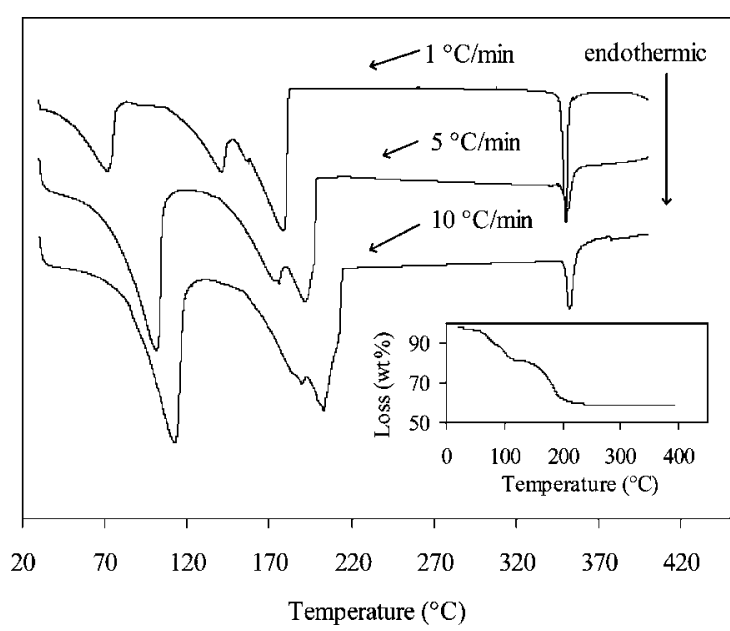

Fig. 4 DSC traces of $\mathrm{Li}_{2} \mathrm{~B}_{12} \mathrm{H}_{12} \cdot 7 \mathrm{NH}_{3}$ with ramp rate of 1,5 and $10{ }^{\circ} \mathrm{C}$ $\mathrm{min}^{-1}$. Inset is the TGA curves with a ramp rate of $5{ }^{\circ} \mathrm{C} \mathrm{min}^{-1}$.

$\mathrm{Rb}_{3} \mathrm{Br}\left[\mathrm{B}_{12} \mathrm{H}_{12}\right]^{11}$ and was attributed to the loss of the symmetry of the icosahedral dianion $\left[\mathrm{B}_{12} \mathrm{H}_{12}\right]^{2-}$. For the ammine complex, however, the symmetry of the boron cage remains, as indicated by the single characteristic stretching absorption peak at $2470 \mathrm{~cm}^{-1}$. As for the IR spectrum of the ammine complex, the peak at $3360 \mathrm{~cm}^{-1}$ and $1150 \mathrm{~cm}^{-1}$ is associated with the characteristic $\mathrm{NH}_{3}$ absorption. ${ }^{12}$ The ammine complex is extremely sensitive to moisture since the strong absorption peak at $3600 \mathrm{~cm}^{-1}$ associated with water was found after the material was exposed to air for $15 \mathrm{~min}$, and the $\mathrm{NH}_{3}$ absorption at $1150 \mathrm{~cm}^{-1}$ disappeared as well.

The thermal stability of the compound can be derived from DSC (Fig. 4) and TGA curves (Fig. 4 inset). There are four endothermic peaks during heating, with the first three peak positions shifting to higher temperature when the ramp rate is increased from $1{ }^{\circ} \mathrm{C} \mathrm{min}^{-1}$ to $10{ }^{\circ} \mathrm{C} \mathrm{min}^{-1}$. Combined with the TGA curve (the inset), it is found that these three peaks are associated with ammonia desorption. The last endothermic peak at $350^{\circ} \mathrm{C}$ is due to a phase change, since there is no weight loss beyond $250{ }^{\circ} \mathrm{C}$ and XRD study of the material heat treated at $370{ }^{\circ} \mathrm{C}$ for $30 \mathrm{~min}$ showed a different pattern than that of the initial complex (see ESI $\dagger$ ). Both TGA and DSC curves indicate that the ammine complex decomposes in steps. As can be found from the TGA curve, after the first step, i.e. around $100{ }^{\circ} \mathrm{C}, 3$ out of the 7 ammonia were discharged, and then the remaining 4 ammonia were released during the second step at about $200{ }^{\circ} \mathrm{C}$. Thus, the ammine complex can give off $43.36 \mathrm{wt} \% \mathrm{NH}_{3}$ at below $200^{\circ} \mathrm{C}$. $\mathrm{Mg}\left(\mathrm{NH}_{3}\right)_{6} \mathrm{Cl}_{2}$ releases six ammonia through three steps: $6 \rightarrow 2,2 \rightarrow 1,1 \rightarrow 0$, at about $170{ }^{\circ} \mathrm{C}, 300{ }^{\circ} \mathrm{C}$ and $400^{\circ} \mathrm{C}$ respectively. ${ }^{3}$ Although these data were obtained using a different technique (temperature programmed desorption) with a different setup, it still shows that $\mathrm{Li}_{2} \mathrm{~B}_{12} \mathrm{H}_{12} \cdot 7 \mathrm{NH}_{3}$ has better desorption behavior, i.e. higher capacity at lower temperatures, which is crucial for real applications.

Our preliminary investigation has shown that no degradation in capacity has been found after 10 cycles, which indicates that $\mathrm{Li}_{2} \mathrm{~B}_{12} \mathrm{H}_{12}$ can reversibly charge and discharge $43.36 \mathrm{wt} \% \mathrm{NH}_{3}$ under such moderate conditions. The noticeable reversibility of this new ammine complex at mild working conditions indicates that it may be a promising candidate for indirect hydrogen storage. Other cations such as calcium, potassium and aluminum can be explored. Our preliminary results have ruled out the ammine complexes of $\mathrm{MgB}_{12} \mathrm{H}_{12}$ and $\mathrm{Na}_{2} \mathrm{~B}_{12} \mathrm{H}_{12}$ due to their low storage capacities.

In summary, anhydrous $\mathrm{Li}_{2} \mathrm{~B}_{12} \mathrm{H}_{12}$ picks up seven ammonia at room temperature under 0.5 bar and it releases all the ammonia under $200^{\circ} \mathrm{C}$; thus, this compound can store $43.36 \mathrm{wt} \% \mathrm{NH}_{3}$ under very mild operating conditions. The remarkable reversibility makes it suitable for ammonia storage or indirect hydrogen storage.

\section{Acknowledgements}

This work was funded by the US Department of Energy, Office of Energy Efficiency and Renewable Energy (EERE) under Contract No. DE-FC3605GO15062 as part of the DOE Metal Hydride Center of Excellence.

\section{Notes and references}

1 S. Satyapal, J. Petrovic, C. Read, G. Thomas and G. Ordaz, Catal. Today, 2007, 120, 246.

2 S.-I. Orimo, Y. Nakamori, J. R. Eliseo, A. Zuttel and C. M. Jensen, Chem. Rev., 2007, 107, 4111.

3 (a) R. Z. Sørensen, J. S. Hummelshøj, A. Klerke, J. B. Reves, T. Vegge, J. K. Nørskov and C. H. Christensen, J. Am. Chem. Soc., 2008, 130, 8660; (b) A. Klerke, C. H. Christensen, J. K. Nørskov and T. Vegge, J. Mater. Chem., 2008, 18, 2304.

4 A. Boisen, S. Dahl, J. K. Nørskov and C. H. Christensen, J. Catal., 2005, 230, 309.

5 P. J. Feibelman, Phys. Today, 2005, 58, 13-14.

6 G. Walker, Solid-State Hydrogen Storage: Materials and Chemistry, Woodhead, Camberidge, 1st edn, 2008, ch. 16, p. 546.

7 I. B. Sivaev, V. I. Bregadze and S. Sjoberg, Collect. Czech. Chem. Commun., 2002, 67, 679.

8 I. Tiritiris and T. Schleid, Z. Anorg. Allg. Chem., 2002, 628, 1411.

9 G. M. Sheldrick, SHELXTL-97: A Structure Solution and Refinement Program, University of Göttingen, Göttingen, Germany, 1998.

10 R. H. Crabtree, P. E. M. Siegbahn, O. Eisenstein, A. L. Rheingold and T. F. Koetzle, Acc. Chem. Res., 1996, 29, 348.

11 I. Tiritiris, J. Weidlein and T. Schleid, Z. Naturforsch., B: Chem. Sci., $2005,60,627$.

12 S. Kagami, T. Onishi and K. Tamaru, J. Chem. Soc., Faraday Trans. 1, 1984, 80, 29. 